\title{
"All Things Are Possible": Towards a Sociological Explanation of Pentecostal Miracles and Healings
}

\author{
Jörg Stolz ${ }^{\dagger}$ \\ Observatoire des religions en Suisse, University of Lausanne
}

Pentecostal miracles and healings have often been described and interpreted, but rarely explained in their sociological workings. As former research implies, actual biomedical effects of Pentecostal healings are possible (the so-called placebo effect), but quite limited. In Pentecostal healing services, however, very impressive miracles and healings are routinely produced: paralytics arise from wheelchairs, cancerous ulcers disappear, legs grow, cavities are mysteriously filled, and the deaf suddenly hear. Drawing on a case study and qualitative interviews, this paper offers a sociological, mechanism-based, explanatory scheme for the observed phenomena. It is argued that a number of "social techniques" (e.g., suggestion, rhythm, music), context factors (e.g., audience size and beliefs), and causal mechanisms (e.g., probability, latency, selection, and editing effects) are combined in an ingenious way in order to produce miracles and healings.

Key words: healing; Pentecostalism; charismatic movement; anthropology of religion; rational

choice theory; theory.

Pentecostalism is one of the fastest growing religions worldwide (Burgess 2006:xiii) and one of its main attractions is miracles and healings. In Pentecostal healing services, paralytics arise from wheelchairs, stiff knees become flexible, cancerous ulcers disappear, and headaches vanish. Speakers receive "words of knowledge" and can foretell healings that are taking place in the audience. The atmosphere is one of miracles and healings, a time in

*Direct correspondence to Jörg Stolz, University of Lausanne, Observatoire des religions en Suisse, Bâtiment Vidy, CH, 1015 Lausanne, Switzerland. E-mail: joerg.stolz@unil.ch.

${ }^{\dagger} I$ thank Barbara Dellwo, Anaïd Lindemann, and Edmée Ballif for their help with data collection and important discussions. I thank Régis Déricquebourg, Olivier Favre, Nicole Durisch Gauthier, Philippe Gilbert, Denise Hafner Stolz, Christophe Monnot, Roberto Motta, Detlef Pollack, Jeanne Rey, Ingrid Storm, David Voas, and three anonymous reviewers for their valuable comments. I thank Christine Rhone for correcting the English version of the paper. The usual disclaimers apply.

(C) The Author 2011. Published by Oxford University Press on behalf of the Association for the Sociology of Religion. All rights reserved. For permissions, please e-mail: journals.permissions@oup.com. 


\section{SOCIOLOGY OF RELIGION}

which—as the speaker tells us_-"all things are possible." Anthropologists have often taken a positive view of alternative healing and have created a rich, mainly descriptive and interpretive literature. However, they have not yet explained with what "social techniques" Pentecostals routinely produce impressive miracles and healings. Critical scholars and doctors, on the other hand, have mainly taken a negative view of Pentecostal healings. While they have pointed to some techniques used, they have great trouble explaining why Pentecostal healing workshops exist in the first place, given that the biomedical effects are slight or nonexistent.

What seem to be missing from the literature are attempts by explanatory, nonnormative sociology. This article therefore asks, first: by what social techniques are miracles and healings in Pentecostal healing workshops produced? Second: why do these workshops continue to persist, even though people might learn over time that these healings and miracles are often greatly exaggerated? In asking these questions, I try to abstain from value judgments and to argue neither for nor against Pentecostal healing. Assuming a special version of "methodological atheism," I do not wish to argue that "miracles are impossible," but try-as I would with any other social phenomenon-to explain as much as possible with sociological tools.

To exemplify my claims, I draw on a case study of a healing workshop that took place during an international healing conference in French-speaking Switzerland as well as on in-depth interviews with participants and the speaker. I argue that a number of "social techniques" (e.g., suggestion, rhythm, music), context factors (e.g., audience size and beliefs), and causal mechanisms (e.g., probability, latency, selection, and editing effects) are combined in order to produce miracles and healings. I show that the model explains a variety of Pentecostal healing phenomena.

\section{ACCOUNTING FOR MIRACULOUS PREDICTIONS AND SUPERNATURAL HEALINGS}

\section{Pentecostal Approach}

Before going into social scientific explanations, we should turn to the way Pentecostals account for miracles and healings. Healings and miracles are highly valued in Pentecostalism and the charismatic movement (Anderson 2002). They belong to the various "gifts" that are given by God to the faithful. In the Pentecostal view, both miraculous "words of knowledge" (supernatural knowledge of facts one could not have known about) and divine healing are undeniable facts. Not only are they rooted in scripture, but also they are visibly occurring on a regular basis both in healing services and in everyday life.

In the Pentecostal view, illnesses of all kinds are not God's work but due to "evil forces," "sin," or "the devil." Divine healing is made possible because Christ has already suffered for humanity's sins on the cross. It can heal any 
illness whatsoever, be it a small ailment (e.g., a headache), a mental problem (such as depression), or very serious physical maladies (e.g., cancer, AIDS). It follows that healing is never just physical, but by definition physical, mental, and spiritual simultaneously. Furthermore, healing is always the work of God and the Holy Spirit, never of the person praying for healing (Warrington 2006:235). Although most Pentecostals nowadays do not reject biomedicine, they see divine healings as clearly more pure and powerful (Andrews 2003:17). Having looked at the Pentecostal explanation, what does social scientific research make of miracles and healings?

\section{Anthropological Approach}

In the social sciences, it is especially anthropologists ${ }^{1}$ and, sometimes, qualitative sociologists who have researched Pentecostal and related healing phenomena. Their approach has mostly been descriptive and interpretive, thus often refraining from causal explanations. Anthropologists readily admit that Pentecostal (or other "alternative") healing often does not have great "physical" effects measured by biomedical standards (Csordas 1988:136).

However, alternative healing may cure their "selves." This is accomplished through reinterpreting the patients' illness in the framework of a given symbol system ("symbolic manipulation") (Csordas 2002). By conducting a ritual, alternative healers convince the patient of a change of meaning of his illness. This may have different beneficial effects. First, meaningless pain is transformed into a manageable burden (Csordas 1988:122; Geertz 1993:105). Second, patients may be empowered. Before, they might have felt helpless; now they feel able to transform and overcome their malady (McGuire 1987:366). Third, patients may be led to change their habitus and lifestyle (e.g., stop drinking) (Laurent 2001:333). Fourth, patients may be integrated into the religious group, providing them with new social capital. All of these results may have additional (though often limited) psychophysical effects, reducing or even eliminating the malady. The latter may especially be the case for problems that were partly or wholly psychosomatic in the first place (Moerman 1979).

When critics say that healers produce "only a placebo effect," these anthropologists answer that, precisely, the placebo effect shows that humans are a socio-psycho-physical entity in which the symbolic may have an effect on the physical (Dow 1986:63; McGuire 1991:228; Moerman 1979:62). Anthropologists have generally shown a rather positive attitude towards alternative healing practices and Pentecostal healing in particular. They insist on the idea that the culturally "dominant" biomedicine should not be used to

${ }^{1}$ I am aware that there are various types of anthropology concerned with healing. My claim is only that some highly respected scholars in anthropology and qualitative sociology hold the views on healing described in the paragraph. 


\section{SOCIOLOGY OF RELIGION}

judge "alternative" medicine. Rather, biomedical and alternative healing systems are incompatible paradigms, which should both have the right to exist (Moerman 1979:60; Rossi 2009). For example, McGuire (1991:5) writes:

A . . notion that must . . . be set aside is the assumption that the medical reality, as promulgated by the dominant health specialists in this culture, is necessarily the "true" reality. From a sociological perspective, this medical definition of reality must be seen as one among many competing conceptions of illness, its causes, and treatment. Medical reality, too, is socially constructed.

While the anthropological approach has produced many important insights, anthropologists-due to their focus on descriptive and interpretive methods and legitimizing impetus-have missed asking some crucial explanatory questions. Specifically, they have not attempted to show which "social techniques" Pentecostal healers and their audiences employ to achieve the social reality of miracles and healings.

\section{Critical Approach}

Turning to the authors I have loosely grouped into a "critical approach," it is as if we entered a different world altogether. These writers from various disciplines have mainly asked if Pentecostal healing has "real" effects according to biomedical standards. Their results are generally negative. ${ }^{2}$ A first group tries to follow up individual cases of alleged healings (Nolen 1975; Randi 1989; Rose 1971; Thomas 1999). Thus, the professional magician Randi (1989:287) writes:

My standards are simple. I need a case that involves a living person, healed of an otherwise non-self-terminating disease, who recovered from that disease as a result of a faith healer's actions and can produce before-and-after evidence to establish that fact. I have failed in any and all cases I have investigated to obtain a response that satisfies these simple requirements.

Some of these authors show what "techniques" healers may use in order to make miracles and healings appear real. How is a leg made to grow? The healer just manipulated the patient's shoe to make it look as if there was growth. A blind person suddenly sees and can tell the number of fingers the healer is holding before his eyes? The patient was not completely blind before. A person in a wheelchair gets up and is able to walk? The person was able to walk before; he was told to sit in the wheelchair brought by the healer. How does the healer know the names and illnesses of individuals in the audience? Before the show, the healer's assistants gathered the information, and the healer memorized the information using mnemonics or else receives it during the show

${ }^{2}$ The publications assembled in this paragraph are very diverse. The case-oriented studies often have a "debunking" character. 
using electronic devices. So much, then, for the follow-up approach and its results.

A second method used to establish the effectiveness of alternative healing is the scientific experiment. In the past years, an increasing number of highquality, randomized experiments on the subject of distant and faith healing have been conducted. In an update of a systematic review, Ernst (2003) concluded that recent rigorous studies "shift the weight of the evidence against the notion that distant healing is more than placebo."

Most of the writers I have placed in the "critical" group see Pentecostal healing quite negatively. James Randi is the most infuriated of them all. $\mathrm{He}$ finds faith healing "disturbing," "ridiculous," and "silly." Often, he is bewildered not just by the boldness of the healers but also by the seeming irrationality of the believers (Randi 1989:109). In fact, all of these writers see Pentecostal healing not only as useless but also as harmful for the individuals engaging in it.

While critical authors have brought some insights to the understanding of Pentecostal healing, their negative value judgments have prevented them from giving satisfactory answers to important questions. Thus, they have been unable to explain just why many Pentecostals persist in believing in their healing even in the face of seemingly contradictory evidence or why they actually help the healers to perform their "social techniques." As a result, they also fail to understand why Pentecostal healing may be successful, as a social enterprise, in the long term.

\section{Explanatory Sociology Approach}

In this article, I want to present yet another approach: explanatory sociology. While this type of sociology remains still untried in the field of Pentecostal miracles and healings, I argue that it can make a valuable contribution especially in those areas where former anthropological or critical approaches tend to be weak.

Following the general tenets of the approach, explanatory sociology tries to take a neutral stance regarding Pentecostal miracles and healings. These phenomena are neither seen positively (as by some anthropologists), nor rejected (as by some of the critical scholars). While neutrality is more an ideal than an attribute of concrete research, explanatory sociology may nevertheless approach the ideal by disregarding whether these practices are "good" or "bad" and attempting only to explain what actually happens.

According to explanatory sociology, a phenomenon is explained if one can show how it results from a set of initial conditions and a generative (and therefore causal) mechanism (Hedström 2005). More specifically, a sociological explanation is given if we can show how an initial situation (macro) leads individuals to react to this situation (micro) and how, through aggregation, these individual reactions combine to form a new social outcome (macro) (Coleman 1990). 


\section{SOCIOLOGY OF RELIGION}

In explanatory sociology of religion, it is important to assume "bounded rationality." We take it as a given that individuals have subjectively "good reasons" for their beliefs and actions. However, we also assume that their ways of creating beliefs may fail due to erroneous inferences, conclusions based on unwarranted assumptions, or motivationally or socially biased evaluations (Boudon 1997; Gilovich 1991; Stolz 2009).

From this perspective, the healing service is a special case of an "interaction system." 3 Due to the causal mechanisms at work in the interaction system, actors are able to produce miracles and healings as emergent "salvation goods" (Stolz 2006). In what follows, we specify the elements and mechanisms of this interaction system.

\section{METHOD}

This is a case study of an AIMG (Association Internationale des Ministères de Guérisons) healing workshop with the speaker Ian Andrews in 2003 in Oron-la-ville, Switzerland. Case studies lend themselves well to an explanatory sociology framework, since they allow for direct observation of causal mechanisms (Miles and Huberman 1994).

\section{Video and Transcription Analysis}

My first main data source is a DVD of the AIMG workshop with accompanying transcript. ${ }^{4}$ The DVD, produced by AIMG, shows 52 minutes of the (almost) uninterrupted workshop. The use of a DVD and transcript has distinctive advantages compared with "plain" observation. Repeated viewing leads to the analysis of audible and visible details, of the distinct temporal structure of the situation, and of the complete interaction as far as it appears on tape. Furthermore, video data are more reliable than field notes in that they may be used by other researchers (Knoblauch 2009:73).

On the downside, video data may lead researchers to the false belief of having "everything," when in fact they only have what is on tape. The point of view of the actors (cognitions, values, preferences) as well as structures and cultural frames that transcend the situation may be blocked out. In our case, the use of additional interviews, participant observation and documentary analysis addresses this concern.

An additional validity issue arises since the religious group itself has produced the video. Presumably, AIMG could have edited the video in such a way

\footnotetext{
${ }^{3}$ I define "interaction system" as the interrelation of individuals perceiving each other as jointly present (compare to Esser 2000:273ff).

${ }^{4}$ I chose the Ian Andrews workshop, since it is typical of AIMG practices and is fully taped. I have attended many workshops, but not this particular one. I prefer to use a case where I have a tape available, rather than one that I have attended but not taped.
} 
as to make the miracles and healings as spectacular as possible to attain their purpose of evangelization. While it is evident that AIMG in fact tries to evangelize, a comparison of what we see on tape and what I have observed in various other AIMG workshops shows that there seems to be very little "effect-enhancing editing."

\section{In-depth Interviews and Participant Observation}

My second data source consists of 23 in-depth interviews. One interview was conducted with the speaker of the workshop, Ian Andrews. A second interview was conducted with Werner Lehmann, one of the two leading figures of AIMG. The other 21 interviews were with attendees of AIMG workshops, meetings, and conferences. The interviews lasted from 60 to 90 minutes; an interview guide was used with main questions and possible probes. Individuals were given as much space as possible in order to develop their understanding of the situation. The interviewees were chosen by contacting evangelical, charismatic, and Pentecostal congregations and by asking if there were people in the congregation who had attended healing workshops or conferences with AIMG. Half of the congregations chosen were in close contact with AIMG through "healing rooms"; the other half were chosen randomly from a comprehensive list of charismatic/Pentecostal congregations. We made a point of finding both regular and occasional attendees.

The resulting sample consists of (excluding Ian Andrews and Werner Lehmann) 14 women and 10 men. ${ }^{6}$ The age range is from 19 to 85; the relatively high mean age (52) fits the mean age in AIMG meetings quite well. The interviews were taped and transcribed. I do not claim any statistical representativeness for this sample but am quite confident that I have captured most of the typical ways of seeing and experiencing the AIMG healings workshops.

\section{Data Analysis}

Concerning the DVD and the accompanying transcript, I made a simultaneous analysis of the video tape and the transcription. Using methods close to "grounded theory," I have interpreted the images and text sequentially, coded and written memos, and watched the DVD countless times (Knoblauch 2009; Strauss and Corbin 1998). For this task, I used ATLASti software. Likewise, the interview transcripts and the documents were sequentially interpreted and coded, and insights introduced into memos. In general, I have worked inductively, trying to let the concepts "emerge" from the analysis. Insights from the video analysis and from interview analysis were "triangulated."

\footnotetext{
${ }^{5}$ Two noteworthy editing activities are an introduction and additional testimonies at the end of the DVD.

${ }^{6}$ In two cases, a spouse and in one case another church member were also present and were interviewed, giving us 21 interviews but 24 participant interviewees.
} 


\section{Methodological Atheism and Its Critique}

Since this paper provides an explanation of how miracles are (at least in part) socially produced, it is necessary to clarify my stance on how scientific explanations and religious truth claims relate to each other. The mainstream position in sociology of religion seems to be some kind of "methodological atheism" as defended by Berger (1990 (1967)) and Hamilton (2001:5). Methodological atheism implies that sociologists will (1) refrain a priori from assessing the (transcendent) truth claims of religions (on the side of the "dependent variable") and (2) refrain from using transcendent factors as explanatory concepts (on the side of the "independent variable").

In this paper, I use methodological atheism in the sense that I do not use transcendent factors on the explanatory (independent) side and that I assume that most of religion's transcendent statements can never be assessed empirically and are therefore not amenable to sociological testing. There is one caveat where I diverge from mainstream methodological atheism (Hamilton 2001). I will not use "a priori bracketing" when looking at the dependent variable. That is, I will not exclude assessment of apparently "transcendent phenomena" a priori, but will try to push analysis with sociological tools as far as possible.

Not accepting "a priori bracketing" is important for my paper in several ways: first, it leads to my premise (based on former research) that the biomedical efficiency of divine healing is rather limited-it is in any case much smaller than suggested in healing workshops. Second, it leads to my central research question: if there are only very limited healings during the workshop-how are the healings then produced with social techniques and how can this be successful in the long term? Third, only against the backdrop of this premise may my findings be readily interpreted. For example, it would be difficult to understand why the speaker uses the "shotgun technique" if it were not for a social production of miracles.

\section{THE HEALING SERVICE IN CONTEXT}

\section{Organizational and Historical Context}

The Association Internationale des Ministères de Guérison (AIMG) [International Association of Healing Ministries] belongs, in a broad sense, to the Pentecostal and charismatic movements. The history of charismatic and Pentecostal "faith healers" goes back to the late nineteenth century (Curtis 2007; Opp 2005). Many of the techniques used since the beginning of these movements have remained surprisingly stable. ${ }^{7}$ In the last decades, however,

${ }^{7}$ The reason for this stability is probably that the social mechanisms involved are on an interactional level and may function independently of larger sociohistoric changes. 
there has been a shift from "big name healers" to a movement in which every Christian is considered able to heal. Individuals with a healing ministry increasingly see themselves as "equippers" who teach others how to pray for the sick. AIMG and Ian Andrews are thinking along these lines.

Pentecostalism in Switzerland is a small minority making up no more than 1 percent of the population. Pentecostals are decidedly middle class (except for immigrant Pentecostal communities) (Stolz and Favre 2005) and are-in contrast to stable evangelical and declining conservative and liberal churchesgrowing. One interesting contextual factor is that both AIMG officials and participants are acutely aware of the "competition" by biomedicine. Since Switzerland is one of the richest countries in the world and has an excellent health care system, divine healing is not as strong, they feel, as in poorer countries.

While AIMG is clearly successful and growing, there is no reason to think that it is the French-speaking Swiss who would be especially prone to react positively to divine healing. The reason for the movement starting in Oron is purely contingent. Individuals wanting to restart a healing movement in the United States contacted Ian Andrews in the UK who suggested the idea to Jean-Luc Trachsel, the current leader of the movement, in Switzerland. AIMG is now spreading to France, Italy, and Belgium as well as to Benin.

\section{The Healing Service}

The healing service with Ian Andrews during the international healing conference took place in 2003 (28 May-1 June) in Oron (canton of Vaud, Switzerland). The conference attracted more than 1,500 persons. It included 11 larger events and 16 healing workshops (of which we analyze one in this paper). The speakers came from Germany, Australia, Burkina Faso, Central Africa, France, Switzerland, England, and the United States.

The healing service took place in a gymnasium. In front of a black cover blocking the sunlight, there was a stage where a music group was standing. On two sides, two gigantic screens retransmitted the events happening on stage. There were about 350 persons, almost all of whom were standing, although the room was equipped with red plastic chairs. The audience was wearing everyday clothes: tee shirts, jeans, colored short-sleeved shirts. The music group was playing gentle worship songs. Many participants raised their hands, some closed their eyes, others gesticulated, and still others hugged. Helpers in front of the stage received the persons wanting to testify, or prayed with individuals wishing to do so.

The speaker, Ian Andrews, was 64 years old at the time of the healing workshop. We see, under some gray hair, a worried face with a deep vertical wrinkle at mid-forehead and eyeglasses with invisible frames. The interpreter, next to him, was a woman of about 35 with discreet golden jewelry and semishort blond hair. Andrews spoke in English, in full sentences or fragments, and 


\section{SOCIOLOGY OF RELIGION}

the interpreter immediately translated his speech into French, adopting his intonations and gestures.

Andrews started out slowly, alternating statements of salvation, instructions to the participants, and theoretical statements. After some minutes, he had a song sung. In a certain manner, Andrews was preparing the participants for the coming of the Holy Spirit who very soon, according to him, was going to take "healing actions." During the meeting, Andrews began to introduce more and more "words of knowledge" into his speech, that is, he transmitted "inspired" sayings of the Holy Spirit about healings simultaneously occurring in the audience. Increasingly often, he invited the persons named in his words of knowledge to come quickly on stage to testify to their healings. His words had effects: many participants came on stage and stated that they had been healed of their illness at that very moment.

\section{HEALINGS, CONFIRMED PREDICTIONS, AND TESTIMONIES}

In order to explain how an atmosphere of miracles and healings is socially produced, I propose the macro-micro-macro model in figure 1 . The model shows how preparation techniques and individual and collective audience attributes combine to produce the perception and feeling of being healed in a certain number of audience members and how these members are then selected and their testimonies edited in order to create the final atmosphere of miracles and healings. The model postulates a number of social mechanisms (probability,

FIGURE 1. Explanatory Model for Pentecostal Miracles and Healings.

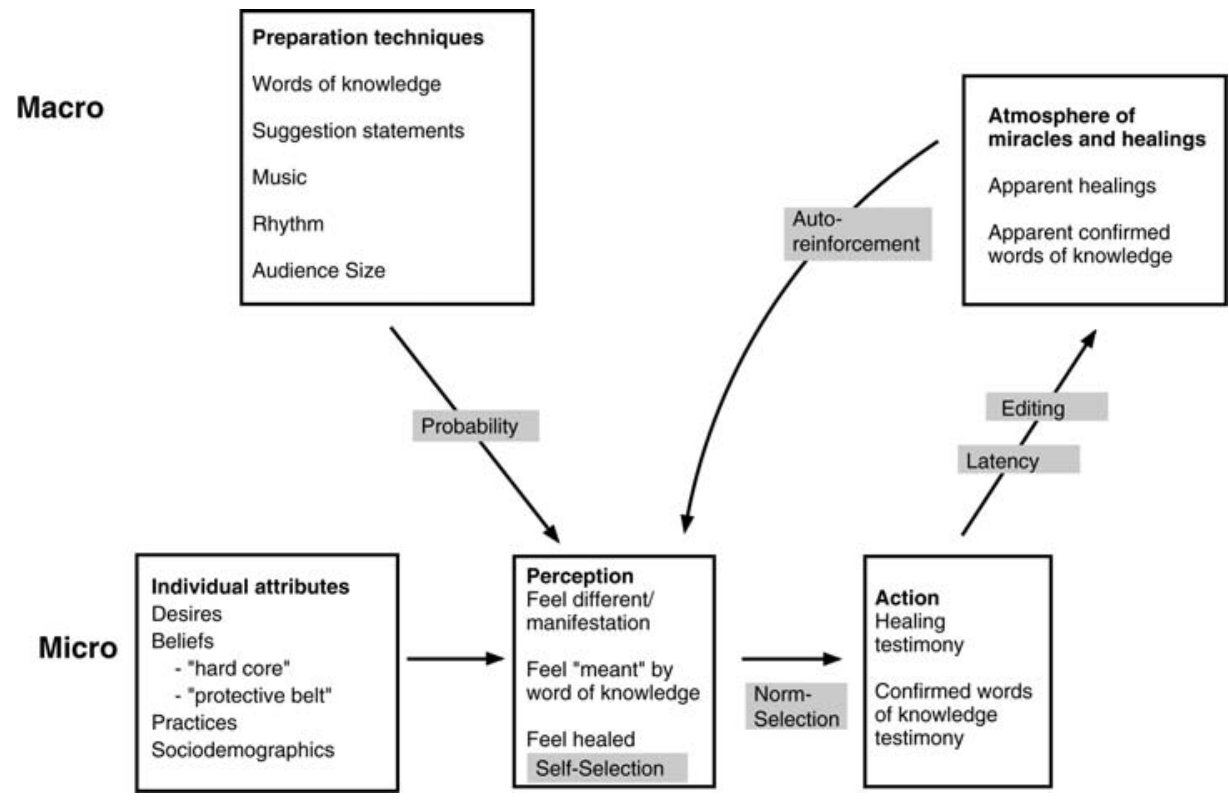


selection, latency, editing and autoreinforcement effects). In what follows, I flesh out these general ideas.

\section{Preparation Techniques}

Andrews uses a whole range of techniques to prepare the participants to receive the subsequent healing.

Suggestion statements and actions. A first class of techniques consists of suggestion statements and actions. These statements and actions are used to elicit altered states of consciousness in the participants and to ensure that they interpret the ensuing perceptions as effects of the Holy Spirit. We find the following types.

Salvation promises. These statements, consisting of ultra-short and positive sentences, affirm as indisputable truth that Jesus is there right now in the auditorium and that he is accomplishing miracles and healings. They are not accompanied by any qualification, justification, attenuation, or reflection. Moreover, they mostly target the here and now as well as all or some of the participants in the auditorium. Here are a few examples: "He is here." "All things are possible." "He is gonna heal multitudes of you this morning." "But Jesus is just touching people. All over this auditorium. Right now."

Body instructions. Andrews also uses various body instructions; he invites the participants to close their eyes, raise their arms, sing, remain quiet, and relax. Moreover, Andrews advises them to forget their illness, to see it as something of little importance, and to concentrate entirely on the Holy Spirit and healing. Readers will note that Andrews's instructions are close to those used in many relaxation techniques, such as autogenic training, guided meditation exercises, or hypnosis. There, too, short, positive sentences as well as body instructions are used in order to induce trance-like states (Heap 2001).

Healing advice. A third element used to induce special "feelings" consists of "theoretical" sentences and instructions. In these sentences, Andrews explains what illness is, how it comes about, and what means may be used to obtain healing. These affirmations have an exclusively practical aim; they explain how the participants can and should change their behavior to be healed.

Words of command. This is an operation by which Andrews heals participants (through the mediation of the Holy Spirit) (compare Csordas 2002:338; 1988:48). Andrews uses words of command in different ways: sometimes, he heals by binding the forces of the occult, darkness, and illness, thus freeing the person from these evil influences. Behind this procedure seems the idea that the name Jesus Christ "contains power" and may thus expulse the illness. The person is "liberated" or else "freed in Jesus."

Andrews: Holy Spirit

Interpreter: Saint-Esprit

Andrews: We take authority over sickness and disease and pain in this meeting right now 


\section{SOCIOLOGY OF RELIGION}

Interpreter: Nous prenons autorité maintenant dans le nom de Jésus sur toute maladie

Andrews: And in the name of Jesus

Interpreter: Et dans le nom de Jésus

Andrews: bind its power

Interpreter: Je lie sa puissance

Andrews: And I loose you from it this morning

Interpreter: Et je vous libère de cela maintenant

Andrews: I loose you in the name of Jesus

Interpreter: Et je vous libère dans le nom de Jésus

At other times, Andrews produces healing by making healthy organs appear. At other times again, Andrews calls the Holy Spirit to go to certain places to carry out its work.

Music, rhythm, and audience size. Another way that participants are prepared for healings in the workshop is by music, a very widespread technique in Pentecostal healing services (Nickel 2002). In this workshop, Andrews starts out with a song. The song has a sweet melody and the lyrics consist of only three words: "Jesus is here." The participants are thus expressing themselves musically while, at the same time, they are ceaselessly told by Andrews that the Holy Spirit is among them right now. In addition, the music group continues to sing these words softly while the healing testimonies are taking place.

Andrew also uses rhythm and pace to prepare his audience. Again, this is a technique mentioned in the literature (Horwatt 1988:131). In our workshop, Andrews starts out very slowly and then increasingly picks up pace, raises his voice, and even shouts. In the second part of the workshop, Andrews also encourages the participants to sing a loud song (Hallelujah). Then again, he lets everybody be very quiet just to "feel the anointing." The attempt to keep up or increase the pace is especially visible during healing testimonies. Countless times Andrews admonishes the participants to act "quickly." Clearly, Andrews would like to give the impression that a "fireworks of healings" is occurring all over the auditorium. Here are two examples:

If you've been healed this morning come quickly, come to the front come.

If you can feel the power of God that's been on you, Come very quickly. Come on.

Run.

A further technique, often overlooked but of central importance, is the size of the group. In our workshop, there were approximately 250-300 people in the room. The room was "full," which is an optimal condition for a faith healing service to "work well." There are several reasons for this. First, a large audience guarantees a relatively high probability that at least some individuals in the audience will have altered body perceptions and/or think that they are "meant" by one of the "words of knowledge". Second, a larger audience allows the individuals to let themselves fall into altered states of consciousness more easily. 
With a small audience, individuals might become self-conscious and feel observed by other members. Third, even 300 people might seem "few," if they are in an enormous hall. For optimal results from the speaker's viewpoint, the size of the room must therefore be adapted to the size of the group (or vice versa). Andrews attributes much importance to this point:

Much depends on the size of a fellowship and their maturity to determine the size of the hall that should be rented. Healing meetings depend on atmosphere, and it will be a big mistake to get over enthusiastic and rent an enormous hall, only to have it one quarter full with people. (Andrews 2003:180)

\section{Giving out Words of Knowledge}

One of the most important preparation techniques used by Andrews is "words of knowledge," that is, predictions as to healings that were supposedly happening right there and then in the audience. According to Pentecostals, words of knowledge belong to the category of "spiritual gifts" and are defined as knowledge revealed by God about facts that the person could not have known in a natural way. Ian Andrews receives these words in different ways. According to him, he sometimes receives a

Picture that comes to my mind very quickly. It's a bit like a flash picture. It flashes in front of your eyes and then it's gone... . Sometimes, I hear a voice. Sometimes I have the pain come to my body, that I know it's not mine. . . . And so when you get that flash, you immediately seize on it and say it. And then see if somebody responds.

Here is an example referring to the healing of breast cancer in the healing workshop:

Andrews: We've got a person straight back through there

Interpreter: Il y a une personne juste là-bas derrière

Andrews: That has got a lump in the breast

Interpreter: Qui a une une tumeur, une grosseur dans le sein

Andrews: I want you to go out to the Lady's room

Interpreter: Et j'aimerais que vous alliez dans la chambre où il y a les dames

Andrews: Feel for it

Interpreter: Et que vous alliez ressentir cela

Andrews: And you'll find it's completely gone

Interpreter: Allez aux toilettes des dames et vous verrez que c'est parti

Altogether, Andrews gives out 17 words of knowledge of varying precision. Nine words of knowledge referred to physical problems, two concerned mental or spiritual problems, and six applied to unspecified problems. In general, they are (like the statements and promises of salvation) very positive and absolute. The people in the auditorium mentioned by Andrews are in the process of 


\section{SOCIOLOGY OF RELIGION}

being completely healed by the Holy Spirit, the pain is disappearing entirely, and the cancerous tumor is vanishing without leaving a trace.

Three attributes of the words of knowledge are important for them to "work." First, there is a noticeable lack of specificity as far as the description of the persons is concerned. In general, Andrews does not know the gender, age, name, home, or even the location of the person in the auditorium. Second, Andrews gives out words of knowledge touching on a whole range of illnesses and afflictions: from stomach ache to a bad neck, from cancer to angina, from back problems to deafness and paralysis. Third, the speaker does not immediately verify if each new word of knowledge is correct in reality, and he does not look for the concerned person in the audience. Rather, after a whole series of words of knowledge, participants come on stage and confirm more or less precisely one or more of the predictions. Before turning to the effects of all of the preparation techniques mentioned, we have to analyze a second causal factor: audience attributes.

\section{Audience Attributes}

In fact, the best preparation would not have much effect if it were not for certain characteristics of the audience. If Andrews had preached in front of 300 hard-core Calvinists, it is likely that not many miracles and healings would have emerged. While I do not have quantitative data for the special case in question, my experience of attending many of AIMG happenings lets me estimate that in an average AIMG meeting, we have 90 percent of individuals with a Charismatic, Pentecostal, or Evangelical background, usually a majority of women (around 60-70 percent), and that average age might hover around 40 to 50 . Our interview data tell us what motives/desires, beliefs, and practices these participants have.

Motives. I found four main reasons why individuals come to these meetings: (1) curiosity, often linked with the fact that they know people who help organize the meeting, (2) desire to get healing for oneself or for a person one brings to the meeting, (3) desire to learn more about healing and be motivated in one's faith, (4) because they have been asked to help by praying for the sick in front of the stage. Often we find a mix of reasons. For our purposes, it is important to note that at least some audience members have the urgent desire to be healed and that many others at least entertain the possibility of being alleviated of some minor affliction. In addition, even if they do not come for healing, the great majority of participants do not attend in a "passive" mode.

Beliefs. Closely linked to the first point are audience beliefs. I propose to describe these beliefs by what I call a "Lakatos-model." Lakatos (1978) argued that research programs by scientists (as well as all kinds of other belief systems like Marxism or Freudism) consist of unfalsifiable "hard-core" beliefs that are surrounded by a "protective belt" of hypotheses, conjectures, ideas, arguments, etc. According to Lakatos (1978:48) it ". . . . is this protective belt of auxiliary 
hypotheses which has to bear the brunt of tests and get adjusted and re-adjusted, or even completely replaced, to defend the thus-hardened core."

Almost all of the AIMG participants that we interviewed argued in a similar way. They entertained a few "hard-core" ideas. Among these, the most frequently cited were (1) God exists; he heals today just as he did in the time of Jesus, (2) God is sovereign; in principle he could heal any and all illness, (3) Jesus has already paid for our sins - and therefore also our illnesses-on the cross, (4) it is always the Holy Spirit, never man, who heals, (5) the Bible tells us that we should pray for the sick. Very often, this "hard core" was explicitly presented as "beyond doubt." Participants said "I cannot doubt that . . .," ". . . there's not a shadow of a doubt," ". . . it's a reality that I absolutely do not doubt...."

On the other hand, many of the elements in the "protective belt" of participants were open to discussion. Three domains of additional hypotheses seemed to be important: a first set of hypotheses states that there are no fixed rules or laws to healing. Healing is "no exact science," it comes in "always different ways," "you cannot make a rule." This absence of rules concerns the place, time, person, and the attributes of healing, as well as the appropriate methods in order to induce healings. A second set of hypotheses states that there are nevertheless techniques that may be used in order to further one's healing. Thus, praying for the sick can be taught and learnt. Faith, openness, and the removal of various "obstacles" can have beneficial effects on healing. A third set of hypotheses states that in healings, natural and supernatural elements may be combined in various ways. Faced with a specific case of healing, one can therefore never be sure how much should be attributed to the Holy Spirit, to what is "human," or to natural causes. For example, as many interviewees told us, it is always possible that individuals will only claim to be healed when in fact they are not. Furthermore, interviewees believed that many maladies were healed by natural causes. With the help of these auxiliary hypotheses, it becomes possible to explain any and all (non)healings while firmly protecting the hard-core beliefs stated above.

Practices. Let us turn to the individual practices of audience members outside the specific meeting. It is important to understand that the great majority of participants are not confronting healing and miracles for the first time when they attend a healing meeting. Rather, most of them practice healing and experience miracles in their everyday lives: they pray for the sick and for themselves when they are ill, in their churches as well as in their family, and on their own. Most have experienced divine healings in the past and are able to narrate key experiences. Many have had words of knowledge for others and/ or have experienced such words themselves.

All of this means that the public is largely familiar with the values and views presented by the speaker Andrews. They already know how to fall into some mild or stronger state of altered state of consciousness and are familiar with the habit of "testifying." This point—completely missed by the "critical" 
authors-becomes important when it comes to interpreting the entire healing service. It means that we cannot distinguish the performer and the audience. Instead, Andrews and (at least much of) the audience are performing together, creating jointly an atmosphere of miracles and healings.

\section{"Feeling Healed" and "Feeling Meant"}

With the help of the social techniques and with the background of audience attributes, Andrews may induce the belief in participants that they are healed or at least meant to be healed. This is done in three (mutually nonexclusive) ways. First, individuals may come to have a different perception of the body and mind and therefore believe that they have been healed or are about to be healed. In the literature, these states are sometimes called "altered states of consciousness" or "trance." In our healing service, the fact that such states are involved is beyond doubt. They are clearly visible on tape and individuals describe them when testifying on stage as well as in our interviews. For example, they narrate having experienced heat, weightlessness, a vision of lights, very strong emotions, peace, impressions of something or someone touching them, a trembling of the whole body, uncontrollable laughter, weeping as well as special feelings in specific limbs (heat, bubbling, tingling). Often, these are immediately imputed to the Holy Spirit, as when individuals say they had, "fallen under the Spirit," or had "felt the freedom and love of God." One interviewee said:

I went to Malley and then they prayed for me and then something just amazing, that is, I felt the power of God go through physically. And that I had never, never felt before in my life, it was like driving me crazy. (Marie)

From an "emic" point of view, the Holy Spirit is at work. From an outside perspective, however, the social techniques described produce the bodily experiences of participants. Second, individuals may have the feeling of being healed or about to be healed since they come to believe that one of the words of knowledge (that predicts a currently happening healing) is "for them," they "feel meant". Many interviewees told us that they often think "this is for me" when a word of knowledge is pronounced. Other times, the word of knowledge seems to fit their case reasonably well, but they nevertheless remain unsure if it is "for them." They also often experience that other people "claim" a word of knowledge that they could have imagined was destined for them or, alternatively, suspect that if they have not been healed by a word of knowledge that seemed to be destined for them, others certainly have. Here's a typical example:

Because for me, it's already happened to me to have a call for me and then you recognize yourself right away because you feel something, it's something physical, it, it, it goes through you from top to bottom, it's just, just talking about it, ha (laughter) there's something happening then, and then you say to yourself - but that's me! That's - that's me. (Annie) 
Why do these words of knowledge "work" from an outside, sociological point of view? First, there is an effect of probability. As seen above, Andrews expresses his predictions very generally and he virtually goes through the list of possible physical and mental problems. It follows that there is a high probability that within a large group at least one person will feel implicated. Second, there is an effect of self-validation. The predictions of Andrews incite the members of the audience to interpret their current situation as phenomena described by him. As soon as individuals agree to recognize Andrews's description in the experiences that they are having and testify accordingly, there is "confirmation" of the prediction. Third, individuals may come to believe that they are healed or about to be healed even in the absence of any "confirming evidence" (such as a word of knowledge or an altered state of consciousness). In these cases, they just "take it on faith."

Note that it is not easy for individuals to know if they "really" have been healed. After all, they have to decide on the spot, without medical assistance and on the grounds of often somewhat shaky indicators. A good example is the following participant who recounts how he thought he was healed and testified, but then found that there had, in fact, been no healing:

Even me, it happened to me one time when I thought my tinnitus had disappeared after a prayer that someone said on stage for people who had tinnitus and the Lord did something then. . . and. . I even went to testify after to say that it had gone away but it was it was too much all at once I couldn't make sure it wasn't quiet enough to make sure. . . . But it seemed to me. (Eduardo)

We thus see that individuals have varied possibilities to get themselves to believe that they have been or are about to be healed. These motivations then lead them to testify.

\section{Testimonies}

A final element of the healing service can be found in the "healing and prediction testimonies." We can define Christian testimonies as statements whereby individuals reveal their Christian faith to others. In the case that interests us, individuals are invited to announce healing testimonies. As a side effect, they may also confirm predictions, thus attesting to further miracles. While healing testimonies and prediction confirmation always go together, it is useful to treat them separately. Let us first look at confirmed predictions.

Testimonies of confirmed predictions. During the healing service several individuals come on stage and confirm Andrews's predictions. The confirmations are sometimes very explicit; one individual starts out by saying: "I'm the one whose neck was healed. I had a car accident. . ..." At other times, the confirmation is made more indirectly, such as when one participant says: "You were talking about occultism, um, about the occult. And last night I had a dream about a very bad spirit." 


\section{SOCIOLOGY OF RELIGION}

From the emic point of view, these happenings may be seen as miracles. But can we account for these happenings from an outside, sociological point of view? Let us first describe more in detail just what kinds of confirmations we are dealing with. From the 17 words of knowledge given out by Andrews, 10 are specific enough that they might be "confirmed." Six of these 10 are then actually confirmed either explicitly or implicitly by testimonies. However, a closer inspection of the confirming testimonies shows that the predictions and the experiences by those who "claim" the word of knowledge often do not match very well. For example, Andrews prophesies that a woman is healed instantaneously and completely from breast cancer. The woman who claims the healing says that her breast is still afflicted by a tumor, but "feels softer than before." In another prediction, Andrews prophesies that a person in the audience "is in the occult" and "knows about power." The person who "claims" this word of knowledge has just had a dream about a bad spirit.

We therefore see what we would have expected in the presence of a shotgun technique and self-selection effect: Andrews "takes a shot" at predicting healings and audience members are selecting themselves by thinking "this is me" and then testifying, even though the "fit" with the prediction might be rather slight.

Healing testimonies. In the workshop, various healings were claimed. One woman can suddenly hear. In the midst of cheers, she holds up her hearing aid and says, "I believe I don't need it anymore." A man claims that a "growth" in his leg is "going away." A woman seems to have been healed after 20 years of depression. Another woman's neck that had been stiff because of a car accident is healed. In the following example, an elderly woman affirms that she has been healed of deafness.

Participant: J'entends, j'entends, j'entends, j'avais besoin de ça (shows hearing aid), j'entends maintenant

Interpreter: I can hear now, I can hear now, halleluiah, halleluiah

Participant: Oh Jésus!

Andrews: How long have you been deaf?

Participant: Oh ça fait longtemps, que j'ai un appareil assez longtemps J'ai un j'ai un appar. . .j'avais un appareil acoustique depuis très longtemps Euh euh euh maintenant il me semble que j'en ai plus besoin!

Interpreter: And now I think I don't need it anymore (shows the hearing aid to everyone). Halleluiah

Andrews: Bless you, bless you, bless you

The testimonies may be seen as small interactions between Andrews, the interpreter, and the testifier; they are most often structured in a very similar manner. Andrews begins with an invitation to speak ("What happened?", "What happened to you?"). One or two short sentences follow in which the person tells his or her illness or problem and how he or she was healed. Then, Andrews sometimes asks the person for details of her story (for example, he 
asks when the depression first began), or else he incites the person to demonstrate her healing (for example, show that she can hear with the formerly deaf ear). The purpose of this is to dramatize the healing. Then, Andrews praises Jesus ("Thank you Jesus," "Isn't Jesus wonderful?") and places his hand on the person's forehead. With this gesture, the person often falls backwards. "Catchers" then hold her up, thus preventing her from injury. In what way are the testifiers healed?

A close look at the testimonies shows that the 24 individuals (20 women, four men) who testify are by far not all "completely healed" as the words of knowledge by Andrews would have had it: 37.5 percent claim to have been healed, 20.8 percent say that they have been partly healed, 25.0 percent of individuals do not seem to be healed, and 16.7 percent individuals do not claim any healing (but testify to an emotional experience). What problems and what types of healing do the participants mention? In 54.2 percent, they pertain to physical illnesses (for example, arthritis, neck problems, cancer). In 29.2 percent, they concern emotional or spiritual problems (mental confusion, bad dream, depression, and grief). In 16.7 percent cases, the persons do not mention a problem, but a joyful experience in which the Holy Spirit intervenes. Again, this state of affairs fits our model well, showing that many things may trigger testifying: perceived healings, bodily and emotional experiences, complete or only expected healings, etc.

Selection effect. Testimonies are not governed only by the desire of individuals to testify. The setup of the healing meeting includes at least three important additional mechanisms that render the testimonies more powerful: selection, editing, and latency. The selection effect is produced by the norm requiring that only healings (but no nonhealings) should be allowed on stage. Very repeatedly, the participants are called to come on stage if they are healed.

Those who have been healed now you can come forward and give a testimony of the healing of God.

If you've been healed this morning come quickly, come to the front come.

If you can hear come up, I want people that have been touched by the Holy Spirit.

The norm is not just repeated countless times by Andrews, it is also enforced by helpers who do a "screening" before leading witnesses to the stage. However, the norm is not always followed. At one interesting point, Andrews sends a person who does not respect the norm back to her seat.

Andrews: How long have you been deaf?

Participant: Oh oh les médecins ils disent que je suis sur...., non non mais je suis ... je n'entends pas bien encore hein....

Interpreter: But she can't hear any . . . yet.

Andrews: Right, but I don't want that, I want people who have been healed. It's the Holy Spirit is doing the healing, not me. 
Editing effect. Another mechanism is an "editing" of the testimonies by Andrews. These techniques make the testimonies more impressive than they would otherwise have been. One technique consists of not going into detail as to what has actually happened and just assuming that the person testifying has been totally healed. Andrews uses this often. He always receives the testimonies in a very positive manner and validates them. Even if the "witnesses" express only very unspecific things, such as a happy face or trembling, Andrews immediately takes it as confirmation of a healing. In the following segment, Andrews has questioned individuals who have been "healed of depression." Since the witnessing woman looks happy, Andrews simply assumes that she has been healed of depression, without going into further detail.

Andrews: Look at this lady

Interpreter: Regardez à cette jeune dame

Andrews: Isn't she beautiful?

Interpreter: Est ce qu'elle n'est pas belle?

Andrews: How long have you been depressed?

Interpreter: Pour combien de temps avez-vous été dépressive?

Participant: Twenty years

Andrews: Twenty?

Participant: Twenty

Interpreter: Pendant vingt ans

Andrews: Twenty years! Look at her

Interpreter: Pendant vingt ans. Regardez-la

Andrews: Oh Jesus loves you

Interpreter: Le Seigneur vous aime

Another way of editing is the dramatization of the healing by emphasizing either the importance of the malady in the past or the completeness of the healing in the present. Thus, Andrews may insist on the fact that a woman has been depressed for 20 years, before finally being healed this day or he may "test" the newly found hearing of another woman by whispering words into her formerly deaf ear.

A final way of editing is the "handling" of nonhealings. When people without a healing succeed in getting on stage (against the norms of the interaction system), Andrews does not take their testimony as evidence that the Holy Spirit has not fulfilled expectations. Rather, he prays for these people and "heals" them on the spot. This is mostly followed by the persons falling to the floor under the power of the Holy Spirit, where they continue lying without further being interviewed. In any case, there is no immediate "confirmation" of their healing, which has the advantage of excluding possible negative messages.

Latency effect. A third mechanism enhancing the effect of testimonies may be called an effect of latency. The fact that the different previsions are not verified one by one but are grouped together in a set of verifications (testimonies) 
masks the fact that (1) many testimonies match the content of the words of knowledge only superficially, (2) many words of knowledge are not confirmed at all, (3) some individuals testify even if they have not been healed in this workshop, but at some other time and place. ${ }^{8}$

Auto-amplifying processes and charisma. We have already cited Ian Andrews as saying that "Healing meetings depend on atmosphere." I agree but must ask why atmosphere is indeed so very important. The reason is that healing services depend on a close interaction between the speaker and the audience. This leads to an important self-reinforcement effect. Thus, if nobody or only a few obtain healing, the speaker and the audience lose confidence, the individuals "cool off," nobody falls into altered states of consciousness, and this results in even fewer healings. Conversely, once a few strong healings have been claimed, this "builds faith" and a healing service can rocket off to a frenzy of miracles and healings.

This also means that the "charisma" of the speaker is highly vulnerable. It helps, of course, to be well known and to have a reputation for miraculous deeds. However, much like a rock star or comedian, if the speaker does not "deliver" on the spot, if he does not succeed in enthralling his audience, his long-earned reputation is not worth a cent. As Weber (1978:1114) noted, charisma depends on success and if there are no healings, the speaker does not seem to be imbued with the Holy Spirit. In our case, Ian Andrews is well known, but by no means a "star." Nevertheless, his technique is good enough to produce quite an important amount of miraculous and healing activity.

\section{APPLYING THE MODEL: THOUGHT EXPERIMENTS AND COMPARISONS}

Explanatory sociology looks for "causal mechanisms." It implies that changing the causes will change the effects. In a social scientist's ideal world, we could do randomized social experiments, setting up healing services with various parameters and then measuring the outcomes. For the moment, I will use other (and less costly) methods: thought experiments and comparisons. In thought experiments, social scientists change the explanatory variables in their models only mentally, trying to imagine what should happen to their dependent variables (Maxwell 2005:58ff.). Furthermore, they may compare their case to other cases in social reality that show these different parameters-and check if their predictions are confirmed. While this is admittedly a rather poor substitute for the "real thing," it nevertheless may lead to interesting insights and plausibility checks. verified.

${ }^{8}$ This contrasts with Andrews's view that "95 percent plus" of words of knowledge are 


\section{SOCIOLOGY OF RELIGION}

Let us imagine what would happen if we took away the self-selection and latency effects. Each healing action or word of knowledge would be uttered for a specific person and immediately verified. We would predict a much higher proportion of falsified healing actions and inapplicable words of knowledge and therefore a less intensive atmosphere of miracles and healings. Interestingly, I have seen a speaker at one AIMG meeting trying to do this. As predicted by our model, a lot of nonhealings came to light and the whole atmosphere in the room got increasingly embarrassed. Shortly after, the leaders of the congregation took over the meeting from the unlucky speaker, resorting to their usual "shotgun technique." The same reasoning explains why healings in "healing rooms," where a number of intercessors pray for one specific individual, are reported to be much less spectacular, not necessarily instantaneous and may easily be "lost" (compare to Csordas 2002:336). ${ }^{9}$

To take a second example: what would happen if we increased the charisma of the speaker, the size of the audience, and the selection effect? Our model would lead us to expect more spectacular healings and miracles. A clear example of this can be seen in the Benny Hinn healing services (Nickel 2002). Hinn is highly charismatic, uses much larger audiences and a strong screening and selection of testifyers. As our model predicts, the miracles are spectacular: Hinn can point at a person and the person is seemingly thrown to the floor by an invisible hand. Hinn screams "power" and about a hundred people seem to fall over like a row of dominoes, etc.

What, finally, would happen if we were able to change audience attributes, for example increase the desire to be healed? Again, our model would lead us to expect more impressive healings and miracles. A good example are the evangelistic meetings by Reinhard Bonnke in various African countries, where the biomedical supply and general conditions according to the Human Development Index are less favorable than in the Western world. The miracles apparently happening on stage are spectacular, including the raising of the dead (see the documentary by Thomas 1999).

\section{BOUNDED RATIONALITY AND THE PERSISTENCE OF HEALING PRACTICES}

Even if we accept everything said thus far in this paper-some major questions remain. The explanatory sociology approach assumes that individuals use (bounded) rationality. Now, it is easy to explain why individuals with incurable maladies turn to faith healing (Gilovich 1991:126). It seems to be rational to try a fringe cure if everything else has failed. However, the majority of

${ }^{9}$ I have to acknowledge that our interviewees also narrate cases in which miraculous healings happened in a small circle of individuals "under their eyes." 
individuals who witness faith healing services are not "terminal cases." If divine healing has only a placebo effect-why are these people often deeply convinced even in the long term?

My position is that Pentecostals use (bounded) rationality just as well as anybody else. Yet, since they begin with different assumptions, they end up believing in the reality of healings even if the evidence (from the outside) seems lacking (compare to Dericquebourg 2004). For lack of space, I can only sketch the argument that will entail three points. First, many participants showed a belief structure that is no less rational than many other belief systems, ideologies, or even scientific theories. As shown above, they hold a "hard core" of beliefs and a protective belt of auxiliary hypotheses that lets them protect the hard core and explain any apparent "falsification."

Second, the reasoning most participants use when evaluating healings and miracles seems to follow a practical, everyday rationality (Esser 1993). In fact, participants were far from thinking that everything they saw in the healing workshops was "true" or "real." Rather, their answers showed a great amount of skepticism. Faced with what was presented as a divine healing, participants thought that it was always possible that the healing would have occurred anyway (naturally), that it was only feigned by the person, or that the person honestly thought she was healed but in fact was not. Respondents pointed out that some testifiers are "human" and just want to be on stage, that others "claim" a healing since they think that they will be healed with a higher probability and that still others only think they are healed because of the "manipulative" atmosphere of healing meetings. ${ }^{10}$ Likewise, however, an apparent nonhealing can just as well have many different reasons and certainly cannot falsify the claim that God heals still today. Respondents produced a long list of arguments (this is the "protective belt") in order to explain nonhealings: if a person has not been healed, this may be the case because the person did not have enough faith (e.g., person looked at the malady, not at Jesus), did not really want to be healed, ${ }^{11}$ was faced with external obstacles (e.g., not lived in accordance with the Bible), was faced with internal obstacles (e.g., anger, nonpardon), or an unfavorable situation (e.g., the speaker did not have enough faith). Alternatively, perhaps a healing has occurred, but due to special circumstances, has not (yet) appeared as such. Thus, it may be that the person was healed, but: she/he was not able to "keep the healing" through faith, the healing has not yet been "manifested" but will do so in the future, the healing arrived in a different way than expected (e.g., emotional instead of physical). ${ }^{12}$

\footnotetext{
${ }^{10}$ Many respondents were acutely aware of the fact that some speakers try to "condition" the audience in order to "produce" more apparent healings.

${ }^{11}$ Many of these explanations were also strongly rejected by various interviewees.

${ }^{12}$ Alternatively, it may be that there has been a healing, but not to the person for whom people had prayed.
} 


\section{SOCIOLOGY OF RELIGION}

Third, most interviewees were able to point to "good evidence" (at least in their eyes) that supported the claim of divine healing (Boudon 1997). Most of them had acquaintances, friends, and relatives who had been healed in spectacular ways in the past. Furthermore, many thought that the Holy Spirit helped them effectively to fight maladies in their everyday life. From an outside perspective, this latter point is easy to understand. First, the human body cures most illnesses by itself. If a person is ill, uses an-even inefficient-medicine or treatment, and then gets better, the cure seems to have worked (Gilovich 1991:128). Second, maladies are never stable. Periods of greater suffering alternate with periods of relief. If individuals use an inefficient treatment when they suffer greatly, chances are that their suffering will diminish because of the normal variability of the malady. Again, the cure will seem to have worked (Nolen 1975:69ff.).

To sum up, the persistence of Pentecostal healing practices is not due to "irrational" beliefs and practices. Pentecostals use completely "normal" (Lakatos-)belief structure, they use practical everyday reasoning, and rest their case on (at least subjectively) "good evidence."

\section{CONCLUSION}

This article has addressed the question of which social techniques produce miracles and healings in Pentecostal healing workshops. It has also tried to explain why such workshops may persist in the long term, even though people, in time, might learn that these healings and miracles are often greatly exaggerated. My answer, concisely, is as follows.

Miracles, that is, confirmed predictions of healings, are explained by the way the "interaction system" works. Andrews uses the "shotgun technique." That is, he calls out a number of supposed healings in the audience, going through a list of possible maladies. Since the audience is large, he has a high probability that at least one person will accept the description as "fitting" himor herself (effect of probability). When this person comes forward to testify, there seems to be a miracle, although the prediction produced its own validation (effect of self-validation). Since predictions are never immediately verified, but only after a certain lapse of time, predictions that are not confirmed are forgotten and predictions whose confirmations match badly are not noticed (effect of latency).

Healings are also produced through the mechanisms of the interaction system. Andrews uses certain preparation techniques (words of knowledge, suggestions, music, rhythm, and audience size) in order to create altered states of consciousness and the feeling of being "meant" in various members of the audience. These audience members have a strong impression of being (about to be) healed. In a next stage, Andrews makes sure that only individuals who have a healing to report are allowed on stage (using norms and helpers). Finally, he 
"edits" the testimonies to make them look much more impressive. If he does this successfully, by way of an effect of autoreinforcement, individuals in the audience will perceive miracles and healings happening, increase their faith in the charisma of the speaker, and have a higher probability of producing yet more healing testimonies.

I have argued that these results are not in conflict with the basic assumption that Pentecostals use (bounded) rationality. Pentecostals have a "normal" belief structure including a "hard core" and a "protective belt" of auxiliary hypotheses, they are often quite skeptical and use practical everyday rationality to explain both healings and nonhealings, and they rest their case on a body of (at least subjectively) "good evidence."

My article seeks to make a theoretical and methodological contribution. Theoretically, I have shown what social mechanisms are at work that create the social reality of "miracles and healings" in a specific Pentecostal healing workshop. Thought experiments and comparisons with other formats show that a wide range of other Pentecostal healing phenomena can also be explained with the model. I have argued that such an explanatory approach has a distinctive contribution to make in comparison with anthropological approaches that do not focus on causal mechanisms as well as in comparison with critical approaches that fail to understand the social context and the beliefs and practices of the actors involved. Methodologically, I have shown that qualitative methods may be used fruitfully in order to do explanatory, mechanism-based sociology. It is simply not true that "causal analysis" can only be done with quantitative methods.

This being a case study, the limits of my argument are clearly visible. The results of case studies are never "representative" for a given population of cases, even if we are dealing with "typical" specimens. Only future research on a wider range of phenomena and including possibly quantitative research designs will tell if this is a promising avenue for research on Pentecostalism. If that happens-I predict—all things are possible.

\section{FUNDING}

This research was partially supported by a research grant from the Faculty of Theology and Study of Religion (FTSR) from the University of Lausanne.

\section{REFERENCES}

Anderson, Allan. 2002. "Pentecostal Approaches to Faith and Healing." International Review of Mission XCI:523-34.

Andrews, Ian. 2003. Equipped to Heal. Columbus, GA: TEC. 


\section{SOCIOLOGY OF RELIGION}

Berger, Peter L. 1990 (1967). The Sacred Canopy: Elements of a Sociological Theory of Religion. New York: Anchor.

Boudon, Raymond. 1997. The Art of Self-Persuasion. London: Polity.

Burgess, Stanley M. 2006. "Introduction." In Encyclopedia of Pentecostal and Charismatic Christianity, edited by S.M. Burgess, xiii-xiv. New York: Routledge.

Coleman, James S. 1990. Foundations of Social Theory. Cambridge, MA: The Belknap Press of Harvard University Press.

Csordas, Thomas J. 1988. "Elements of Charismatic Persuasion and Healing." Medical Anthropology Quarterly 2:121-42.

- 2002. "The Rhetoric of Transformation in Ritual Healing." In Body, Meaning, Healing, edited by T.J. Csordas, 11-87. New York: Palgrave Macmillan.

Curtis, Heather D. 2007. Faith in the Great Physician. Suffering and Divine Healing in American Culture, 1860-1900. Baltimore, MD: The Johns Hopkins University Press.

Dericquebourg, Régis. 2004. "Comment les thérapies religieuses sont-elles plausibles?" Politico Hermetica 18:11-25.

Dow, James. 1986. "Universal Aspects of Symbolic Healing: A Theoretical Synthesis." American Anthropologist, New Series 88:56-69.

Ernst, Edzard. 2003. "Distant Healing - an 'Update' of a Systematic Review." Wiener Klinische Wochenschrift 115:241-45.

Esser, Hartmut. 1993. "The Rationality of Everyday Behavior. A Rational Choice Reconstruction of the Theory of Action by Alfred Schütz." Rationality and Society 5:7-31.

- 2000. Soziologie. Spezielle Grundlagen. Band 2: Die Konstruktion der Gesellschaft. Frankfurt: Campus.

Geertz, Clifford, ed. 1993. "Religion as a Cultural System." In The Interpretation of Cultures. Selected Essays, 87-125. London: Fontana.

Gilovich, Thomas. 1991. How We Know What Isn't So. The Fallibility of Human Reason in Everyday Life. New York: The Free Press.

Hamilton, Malcolm. 2001. The Sociology of Religion. Theoretical and Comparative Perspectives. 2nd ed. London: Routledge.

Heap, Michael. 2001. "The Nature of Hypnosis." A report prepared by a Working Party at the request of The Professional Affairs Board of The British Psychological Society. Leicester: The British Psychological Society.

Hedström, Peter. 2005. Dissecting the Social. On the Principles of Analytical Sociology. Cambridge: Cambridge University Press.

Horwatt, Karin. 1988. "The Shamanic Complex in the Pentecostal Church." ETHOS $16: 128-45$.

Knoblauch, Hubert. 2009. "Videography. Focused Ethnography and Video Analysis." In Video Analysis: Methodology and Methods. Qualitative Audiovisual Data Analysis in Sociology. 2nd ed. edited by H. Knoblauch, B. Schnettler, J. Raab, and H.-G. Soeffner, 69-83. Frankfurt am Main: Peter Lang.

Lakatos, Imre. 1978. The Methodology of Scientific Research Programmes. Philosophical Papers, vol. 1. Cambridge: Cambridge University Press.

Laurent, Pierre-Joseph. 2001. "The Faith-Healers of the Assemblies of God in Burkina Faso: Taking Responsibility for Diseases Related to 'Living Together'." Social Compass 48:333-51.

Maxwell, Joseph A. 2005. Qualitative Research Design. An Interactive Approach, vol. 41. 2nd ed. Applied Social Research Methods Series. Thousand Oaks, CA: Sage.

McGuire, Meredith B. 1987. "Ritual, Symbolism, and Healing." Social Compass 34:365-79. Press. 
Miles, Matthew B., and Michael A. Huberman. 1994. Qualitative Data Analysis. An Expanded Sourcebook. Thousand Oaks, CA: Sage.

Moerman, Daniel E. 1979. "Anthropology of Symbolic Healing." Current Anthropology 20:59-80.

Nickel, Joe. 2002. "Benny Hinn: Healer or Hypnotist?" Skeptical Inquirer 26.3 (May/June). Retrieved 1 March 2011 (http://www.csicop.org/si/show/benny_hinn_healer_or_hypnotist).

Nolen, William A. 1975. Healing: A Doctor in Search of a Miracle. New York: Random House.

Opp, James. 2005. The Lord for the Body. Religion, Medicine, and Protestant Faith Healing in Canada, 1880-1930. Montreal and Kingston: McGill-Queen's University Press.

Randi, James. 1989. The Faith Healers. New, Updated Edition. Amherst, NY: Prometheus.

Rose, Louis 1971. Faith Healing. Harmondsworth, UK: Penguin.

Rossi, Ilario. 2009. "Pluralité religieuse, médecine et santé: recoupements et interactions." In La nouvelle Suisse religieuse. Risques et chances de sa diversité, edited by M. Bauman, and J. Stolz, 337-52. Genève: Labor et Fides.

Stolz, Jörg, and Oliver Favre. 2005. "The Evangelical Milieu. Defining Criteria and Reproduction across the Generations." Social Compass 52:169-83.

Stolz, Jörg. 2006. "Salvation Goods and Religious Markets: Integrating Rational Choice and Weberian Perspectives." Social Compass 53:13-32.

-. 2009 "Gods and Social Mechanisms. New Perspectives for an Explanatory Sociology of Religion." In Raymond Boudon. A Life in Sociology, edited by M. Cherkaoui, and and P. Hamilton, 171-88. Oxford: Bardwell.

Strauss, Anselm, and Juliet Corbin. 1998. Basics of Qualitative Research. Techniques and Procedures for Developing Grounded Theory. 2nd ed. Thousand Oaks, CA: Sage.

Thomas, Antony. 1999. A Question of Miracles. Documentary. http://www.imdb.com/title/ tt0447686/.

Warrington, Keith. 2006. "Gifts of Healing." In Encyclopedia of Pentecostal and Charismatic Christianity, edited by S.M. Burgess, 232-36. New York: Routledge.

Weber, Max. 1978. Economy and Society. An Outline of Interpretive Sociology. Berkeley: University of California Press. 